Int. J. Dev. Biol. 55: 703-712

doi: $10.1387 / \mathrm{ijdb} .113418 \mathrm{mp}$

\title{
Four decades of discovery in breast cancer research and treatment - an interview with V. Craig Jordan
}

\author{
MARC POIROT* \\ Directeur de Recherche à I'INSERM, INSERM UMR 1037, University of Toulouse III, Toulouse, France
}

\begin{abstract}
V. Craig Jordan is a pioneer in the molecular pharmacology and therapeutics of breast cancer. As a teenager, he wanted to develop drugs to treat cancer, but at the time in the 1960s, this was unfashionable. Nevertheless, he saw an opportunity and through his mentors, trained himself to re-invent a failed "morning-after pill" to become tamoxifen, the gold standard for the treatment and prevention of breast cancer. It is estimated that at least a million women worldwide are alive today because of the clinical application of Jordan's laboratory research. Throughout his career, he has always looked at "the good, the bad and the ugly" of tamoxifen. He was the first to raise concerns about the possibility of tamoxifen increasing endometrial cancer. He described selective estrogen receptor modulation (SERM) and he was the first to describe both the bone protective effects and the breast chemopreventive effects of raloxifene. Raloxifene did not increase endometrial cancer and is now used to prevent breast cancer and osteoporosis. The scientific strategy he introduced of using long term therapy for treatment and prevention caused him to study acquired drug resistance to SERMs. He made the paradoxical discovery that physiological estrogen can be used to treat and to prevent breast cancer once exhaustive antihormone resistance develops. His philosophy for his four decades of discovery has been to use the conversation between the laboratory and the clinic to improve women's health.
\end{abstract}

KEY WORDS: tamoxifen, raloxifene, acquired antihormone resistance, estrogen, nonsteroidal antiestrogen, selective estrogen receptor modulator (SERM), estradiol-induced apoptosis

The past is never dead. It is not even the past. William Faulkner

Tamoxifen, originally classified as a nonsteroidal antiestrogen but now known as the first selective estrogen receptor modulator (SERM), is a pioneering medicine that for more than twenty years was the gold standard for the adjuvant treatment of breast cancer in pre and postmenopausal patients with estrogen receptor (ER)-positive tumors (Jordan, 2003). Millions of women continue to live longer and healthier lives because of tamoxifen treatment. Tamoxifen is also a pioneering medicine, as it is the first drug to be approved in the United States of America by the Food \& Drug Administration (FDA) for the reduction of the incidence of breast cancer in high risk pre and postmenopausal women (Jordan, 2007).

Craig Jordan grew up with a passion for chemistry, but was specifically intrigued by the prospect of using organic chemistry to design drugs to treat cancer. At the age of thirteen, his mother allowed him to convert his bedroom into a chemistry laboratory, where he often got into difficulties during his experiments, either setting the curtains on fire as a rather over reactive experiment was being thrown out of the window, or destroying the lawn outside. However, he did convince his mother that by using the chemistry of fertilizers, he could re-grow the lawn again, but when he did, it came out an interesting shade of blue! Craig had a passion for teaching, and the chemistry and biology teachers at his school, Moseley Hall Grammar School in Cheadle, Cheshire, England allowed him to have a laboratory to teach biochemistry. It was these same teachers who convinced his parents that he should apply

Abbreviations used in this paper: AACR, American Association for Cancer Research; ASCO, American Society of Clinical Oncology; CEE, conjugated equine estrogen, DES, diethylstilbestrol; DMBA, dimethylbenzanthracene; EBCTCG, Early Breast Cancer Trialists' Collaborative Group; ECOG, Eastern Cooperative Oncology Group; ER, estrogen receptor; FDA, Food \& Drug Administration; ICI, Imperial Chemical Industries; SERM, selective estrogen receptor modulator; STAR, Study of Tamoxifen and Raloxifene; TGF $\alpha$, transforming growth factor alpha; WFEB, Worcester Foundation for Experimental Biology; WHI, Women's Health Initiative.

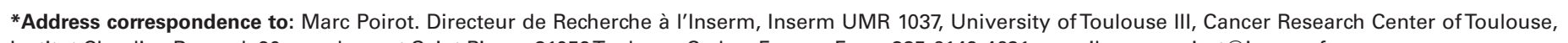
Institut Claudius Regaud, 20, rue du pont Saint Pierre, 31052Toulouse Cedex, France. Fax: +335-6142-4631. e-mail: marc.poirot@inserm.fr

Final, author-corrected PDF published online: 14 October 2011.

ISSN: Online 1696-3547, Print 0214-6282

(C) 2011 UBC Press

Printed in Spain 


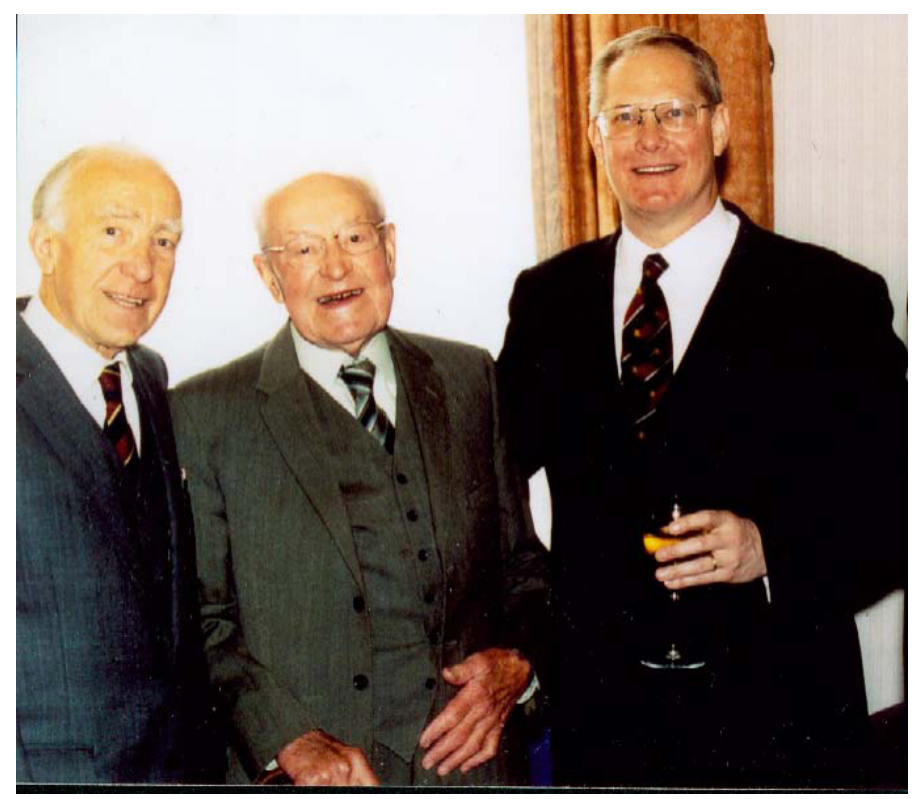

Fig. 1. Before the ceremony for the degree of Doctor of Medicine honoris causa at Leeds University on the 18th of July, 2001. Dr. Edward R. Clark, my PhD supervisor (1969-1972) (left) and Dr. Ronnie Kaye, Head of my degree course (1965-1969) (center), formally from the Department of Pharmacology, University of Leeds, England. I am on the right side with my signature glass of Burgundy.

to university. By contrast, Craig was more content with the idea of becoming an organic chemistry technician at the research laboratories of Imperial Chemical Industries (ICI) near where he lived.

Craig was given an opportunity for interview at only one university (Leeds University, West Yorkshire, England), but he succeeded in convincing the two faculty interviewers, Dr. Ronnie Kaye and Dr. Edward Clark, that he should have a chance in the Pharmacology Department. Years later, Craig found out that the reason he was given an interview was that they had been intrigued at the Headmaster's letter, which stated the candidate was "an unusual young man" and then repeated the statement in

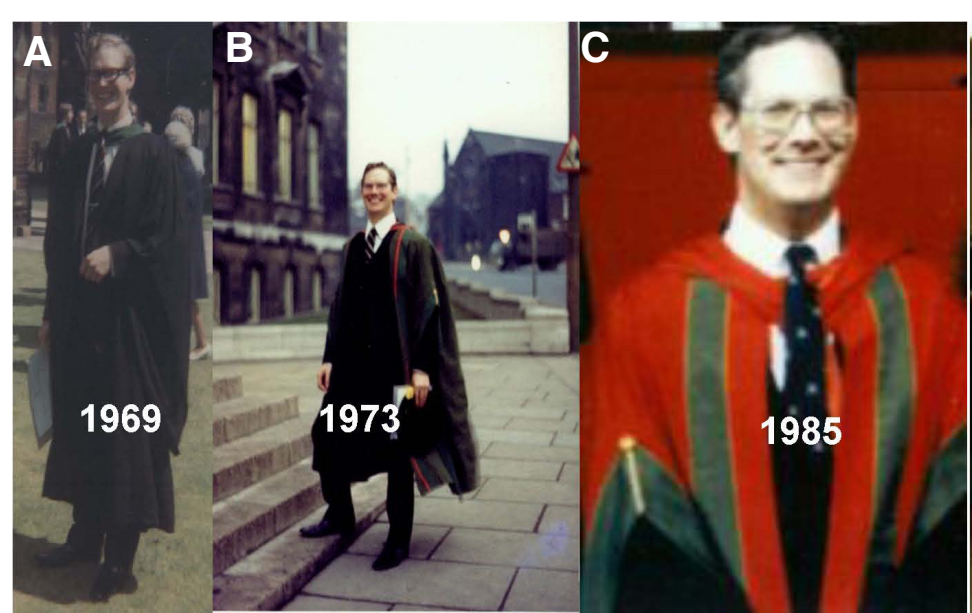

Fig. 2. I always love dressing up! The University of Leeds is my alma mater, and I have attended four ceremonies there: (A) Bachelor of Science, First Class Honours (1969), (B) Doctor of Philosophy (1973), (C) Doctor of Science, earned by examination. A select Committee evaluated my refereed publications to establish my contribution to Science (1985) and (D) Honorary Doctor of Medicine for humanitarian research (2001).

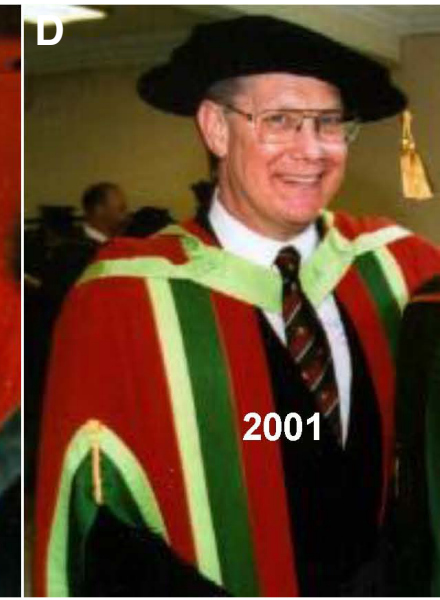

capitals. On July 182001 , Craig received the first honorary Doctor of Medicine degree from the University of Leeds for humanitarian research that has changed healthcare. The citation, presented by the Chancellor Lord Melvyn Bragg, starts: "Craig Jordan is one of the most distinguished medical scientists of the last one hundred years." He was delighted to be able to invite Drs. Clark and Kaye to the luncheon and the ceremony (Fig. 1). These were the two individuals who talent spotted Craig; Dr. Kaye was his tutor for his four years as an undergraduate, and Dr. Clark persuaded him to become a graduate student armed with the last available Medical Research Council studentship in the United Kingdom for the year 1969 (Fig. 2). Someone had declined their studentship, thus allowing Craig to do a Ph.D! Dr. Clark's project, that Craig found so attractive, was the prospect of extracting the estrogen receptor (ER) from the rodent uterus, purifying it and then crystallizing the ER protein with an estrogen and a nonsteroidal antiestrogen. The x-ray crystallography would be completed at the Astbury Department of Biophysics at the University of Leeds and all the work was estimated to take the three years of the scholarship. At that time, the nonsteroidal antiestrogens had failed to fulfill their promise in the pharmaceutical industry as "morning-after pills"; they were perfect in rats, but in women they did exactly the opposite and enhanced fertility by inducing ovulation.

The project in crystallizing the ER did not go as planned, so he rapidly changed his topic with a new title: "A study of the oestrogenic and anti-oestrogenic activities of some substituted triphenylethylenes and triphenylethanes" (Fig. 3). This was a good strategic research choice, as no one has yet succeeded in crystallizing the whole ER with either an estrogen or antiestrogen. But further difficulties were to arise in Craig's journey to a career in cancer research.

As a PhD student, Craig was talent spotted for an immediate tenure track faculty position because of his skill as a lecturer. $\mathrm{He}$ had no publications and his PhD topic was going nowhere. No one was recommending careers in failed contraceptives! During the interview with the University Committee charged with making the appointment, he was told that he would have to go to America to get his BTA (been to America) before he could start the job. First, however, he had to get a PhD, and to do that, it had to be exam-

ined. However, the University could find no one in the country qualified for the task. Sir Charles Dodds, the discoverer of the synthetic estrogen, diethylstilbestrol (DES), declined with regrets as he had not kept up with the literature for the past twenty years! But here is where luck and chance take control. He was in the right place at the right time and by meeting the right people, changed medicine.

Dr. Arthur Walpole was Head of the Fertility Control Program at ICl's Pharmaceuticals Division and a personal friend of the Chairman of Craig's Pharmacology Department. The University reluctantly accepted 
Dr. Walpole (despite the fact that he was from industry!) to be Craig's examiner and he was also able to organize a two year visit to the Worcester Foundation for Experimental Biology (WFEB) in Shrewsbury, Massachusetts to study with Dr. Michael Harper on new methods of contraception. Harper and Walpole had completed all the early work on ICI 46,474 as a contraceptive at ICI Pharmaceuticals in the early 1960's. Craig vividly remembers the transatlantic telephone call with Dr. Harper: "Can you come in September?", "Will $\$ 12,000$ a year be enough?" and "Will you work on prostaglandins?" "Yes, yes, yes" he replied and went off to the library to find out what prostaglandins were! But when he got to the WFEB in September 1972, he was told that Dr. Harper had gone to Geneva to be Head of Contraception Research at the World Health Organization. Craig was told to sit down, write up what he would do for the next two years and organize his own laboratory. He was now an independent investigator.

A phone call to Dr. Walpole explained his dilemma at the WFEB but he felt that there was an opportunity for the failed morning-after pill, ICl 46,474 to be used for the treatment of breast cancer. This call was rewarded by Dr. Walpole arranging for funding and contacts with Ms. Lois Trench at $\mathrm{ICl}$ America for Craig to conduct the translational research on the drug that would become tamoxifen. As an independent Investigator, the research funding from $\mathrm{ICI}$ was an unrestricted research grant, but as Craig was not a cancer research scientist and he was at WFEB, the home of the oral contraceptive, what was the first step to be? Again, what's important is who you meet. After the National Cancer Act in 1971, the WFEB Director had made the decision to bring a cancer research specialist onto the Board of Scientific Advisors to help with future funding opportunities in hormones and cancer research. Dr. Elwood Jensen was the Director of the Ben May Laboratory for Cancer Research in Chicago, Illinois and was credited with the translational research where he described the ER in immature rat estrogen target tissues and then used this knowledge to propose a test for the hormone dependency of metastatic breast cancers. Simply stated, if the ER is absent in the tumor, the patient was unlikely to respond to endocrine ablation (oophorectomy, adrenalectomy or hypophysectomy), but if the tumor was ER-positive, there was a high probability that the tumor would respond to estrogen withdrawal. It was a practical test to avoid morbidity from unnecessary operations that require hospitalization.

Craig spent the day with Dr. Elwood Jensen in November 1972 and told him what he wanted to do with $\mathrm{ICI} 46,474$. Craig subsequently traveled to the Ben May Laboratory for Cancer Research to be taught techniques of ER analysis and to learn all about the dimethylbenzanthracene (DMBA) rat mammary carcinoma model and then to Dr. Bill McGuire's laboratory in San Antonio, Texas to learn complementary analytical methods for the ER. Armed with these techniques and resources from ICI throughout the 1970s (his first decade of discovery), he created the laboratory principles of targeting the tumor ER and advocating the use of long term adjuvant tamoxifen therapy as the appropriate clinical strategy to save lives (Fig. 4) (Jordan and Koerner 1975; Jordan and Allen 1980).
This proposition by Craig was not at all popular, as throughout the 1970 s and 1980s in the United Kingdom, it was strongly believed there was no correlation between tamoxifen use and the presence of the ER in breast tumors. Additionally nobody was interested in a new antihormone therapy, as combination cytotoxic chemotherapy was king. It was going to cure cancer. However, Craig persevered and had the courage of his convictions that his laboratory research would save lives. As it turned out, tamoxifen has probably saved more lives than any other cancer therapeutic drug.

Craig also learned an important lesson at the WFEB around the time he was to leave and return to Leeds. A Senior Scientist at the WFEB, Dr. Eliahu Caspi, invited Craig to his office for an interview to explore the possibility of Craig staying at the WFEB. Craig recalls this was a very frightening experience, for Dr. Caspi had a no-nonsense personality, judged people and said what he thought. He stated that he had been asked to evaluate my C.V., as everybody was of the opinion that I would be a useful asset at the WFEB. He stared at Craig across the desk and said, "You don't have a C.V., as you have no publications." After the initial shock, Craig responded, "But I haven't discovered anything yet." The advice Craig received was some of the best advice he had received thus far in his career. He was told "to tell them the story so far and link together several related publications to create a theme." Craig has done this ever since, creating the theme of tamoxifen. In 1998, with the release of the successful chemoprevention trial with tamoxifen, Craig was referred to as the "Father of Tamoxifen" by the Chicago Tribune, a title that has stuck to this day.

Although many people published using tamoxifen in their studies as a laboratory tool or used it in the 1960s in reproduction research, Craig's focus from the outset was clear; the goal was to develop a medicine for the treatment and prevention of breast cancer (he conducted the first chemopreventive study in the laboratory in 1974 [Jordan, 1976], three years before the drug was approved by the FDA for the treatment of metastatic breast cancer in postmenopausal women). Craig stresses that but for the unrestricted support from $\mathrm{ICl}$, meeting the right people and his uncompromising 


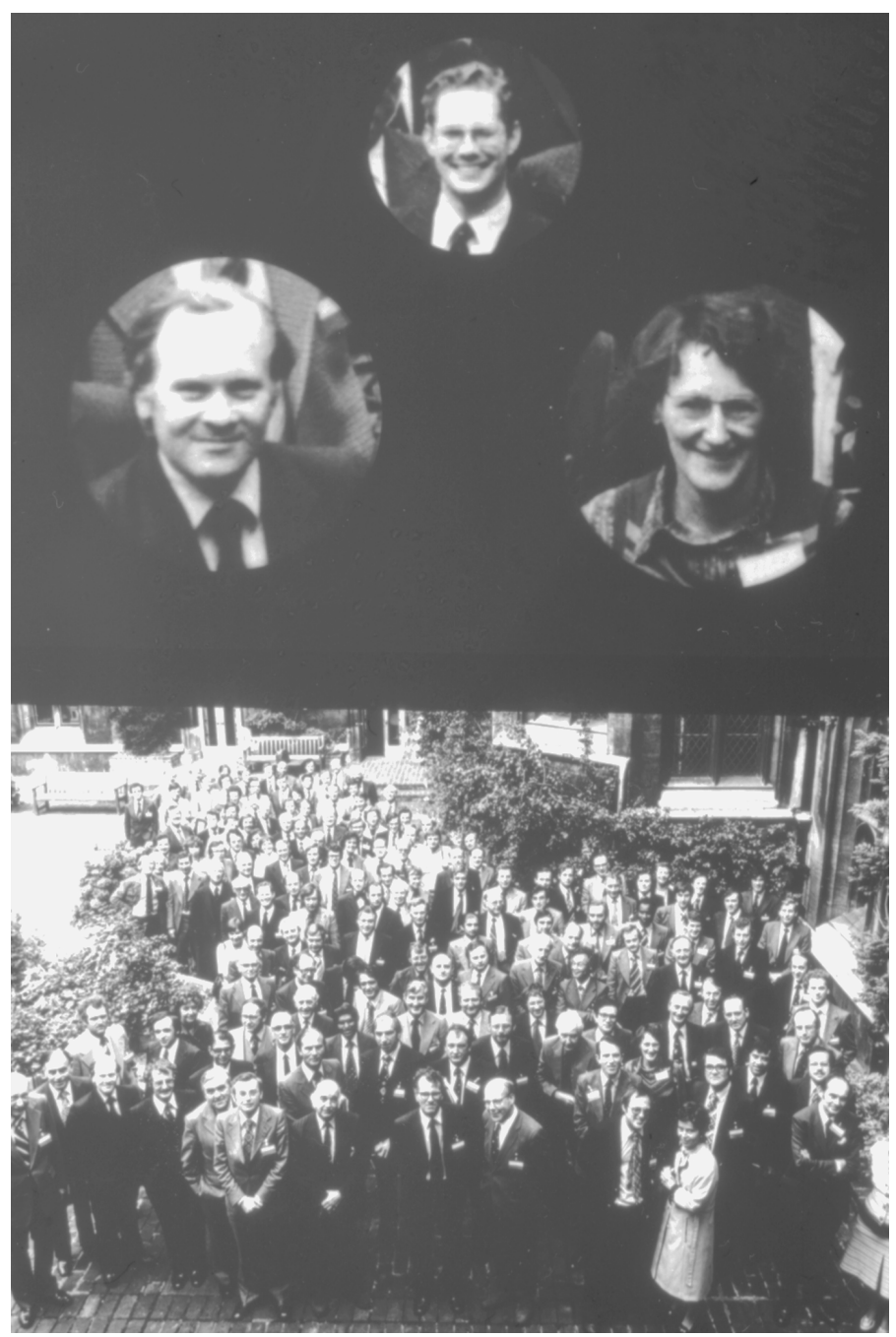

Fig. 4. The Imperial Chemical Industries (ICI) Pharmaceuticals Meeting at King's College, Cambridge in the summer of 1977. The goal of the meeting was physician education about research being done with tamoxifen. This was the first time I presented in public my ideas about targeting the tumor estrogen receptor and using long term treatment with tamoxifen as the best strategy to be applied to adjuvant therapy (Jordan V.C. ,1978. Reviews on Endocrine-related Cancer 49-55). However, the major presentation that made everything change clinically was in Arizona in 1979 (Jordan, 1979). In the above picture, Michael Baum (right), was the Chair of the session at King's College and stated that they had plans to use two years of tamoxifen as an adjuvant therapy (on a hunch). Helen Stewart (left), was considering starting a pilot trial in Scotland using five years of adjuvant tamoxifen for the treatment of patients. For the placebo arm, patients would be treated with tamoxifen at first recurrence. If toxicity was acceptable, they would move forward to test the idea of early long term treatment or late treatment at first recurrence. Both trials showed survival advantages for long term adjuvant tamoxifen. The week after the King's College Meeting, I was at the University of Wisconsin at their Comprehensive Cancer Center to convince clinicians of the Eastern Cooperative Oncology Group (ECOG) that longer was going to be better. At the time, tamoxifen was not on the market in America but I was talent spotted by Paul Carbone, the Head of ECOG and the Director of the Comprehensive Cancer Center, to be recruited to the University of Wisconsin, Department of Human Oncology. Eventually, I would be the Director of their Breast Cancer Research and Treatment Program. determination (many referred to this at the time as poor career judgment), tamoxifen would probably not have happened. Scientists at $\mathrm{ICl}$ did not conduct any studies with the drug as an antitumor agent. Indeed, in late 1972, all of the data with $\mathrm{ICl} 46,474$ was reviewed and the Research Director terminated clinical trials and stopped the development project. The Marketing Department had decided that a treatment for metastatic breast cancer was not going to generate sufficient revenue.

Arthur Walpole was towards the end of his career and chose to take early retirement, but only agreed to remain an employee if funds could be given to a young man he had met, Craig Jordan, who (as he did) wanted to turn ICl 46,474 into a drug to treat breast cancer. Walpole and Craig subsequently worked together on an ICI/University joint research scheme when Craig returned as Lecturer in the Department of Pharmacology at the University of Leeds in September 1974. Earlier in his career, Dr. Walpole was an accomplished cancer research scientist, but had not been allowed to work in this area by $\mathrm{ICI}$ because fertility control was considered to be potentially more lucrative (Jordan, 1988). Dr. Walpole died suddenly on July 2, 1977 before he could witness the success of Craig's laboratory strategy for the treatment and prevention of breast cancer.

The clinical development of tamoxifen was very progressive and validated all your assumptions. Could you tell us how you were involved in the clinical evaluation and how you convinced the company to invest in what may have been very challenging trials?

I think it's fair to say that this was not the real story, but the real story is unbelievable. I have always considered my research as being a conversation between the laboratory and the clinic, and I had the privilege of first introducing tamoxifen to clinical trials' organizations in America. My objective was to provide a scientific rationale for the clinical studies in treatment and prevention. My research and qualifications were required to obtain approval for tamoxifen as a medicine in both Japan and Germany, and I was delighted to be the only person invited from outside of ICI Pharmaceuticals to attend a celebration in 1977, of the Queen's Award for Technological Achievement for tamoxifen. The surprising part about the tamoxifen story is that although patents for the drug were obtained by ICI Pharmaceuticals around the world, in the mid-1960's, these same patents were denied in the United States of America. Thus, all of the work I was completing on the antitumor actions of tamoxifen in the United States was done without patent protection for $\mathrm{ICl}$. Looked at another way, it was clear that all the other pharmaceutical companies had no interest in the clinical development of tamoxifen, because either the drug was not going to work very well or not generate enough revenue. But it was my clinical strategy of long term adjuvant therapy that saved lives and made revenues (Jordan, 2008 a). Clinical testing went ahead and when the patents expired in the rest of the world, $\mathrm{ICI}$ was awarded the patent for the use of tamoxifen in the treatment of breast cancer in 1985, but back dated to the original patent application in 1965. Now, extended adjuvant therapy was the practical solution for effective treatment. Thus, for the next twenty years, ICI was able to generate enormous revenues in the United States, as tamoxifen was the standard of care for long term adjuvant tamoxifen therapy and the only game in town. This money catalyzed the advent of ICl marketing antiandrogens for prostate cancer and the aromatase inhibitors for breast cancer. 
Watching your scientific activity since the beginning, you always seem fascinated by the development of small molecules since their conception up to their development. Is that what gives you much fun in your work?

I absolutely love experiments involving the structure function relationships of the antiestrogens. My basic scientific research has been to create models of gene modulation or replication to determine the structure of the ER antiestrogen complex that subsequently could be interrogated. This passion resulted in a whole series of publications focused on the modulation of the prolactin gene (Lieberman, et al., 1983 a, b; Jordan and Lieberman, 1984) which then went through a metamorphosis to study the modulation of the SERM ER complex and the way that the ligand can interact with specific amino acids, thereby switching on or switching off the complex at target genes (Wolf and Jordan, 1994). We actually found the only natural mutation of the human ER in a laboratory model of tamoxifen-stimulated tumor growth. We engineered the mutant ER into ER-negative breast cancer cells and found it would make the antiestrogen, raloxifene, an estrogen at the transforming growth factor alpha (TGF $\alpha$ ) target gene. For me, this was important as one amino acid in the ER could change the pharmacology of raloxifene. In other words, this provided a fascinating insight into the relationship of the antiestrogenic side chain and a specific amino acid at the surface of the ER protein (Levenson and Jordan, 1998; MacGregor-Schafer, et al., 2000; Liu et al., 2001, 2002).

\section{Do you think that a drug may have a commercial future in the chemoprevention of cancer?}

As you know, we have made enormous progress with advancing the failed breast cancer drug, raloxifene, and millions of women are now benefiting from its use for the treatment of osteoporosis, but with a reduction in breast cancer incidence at the same time. This is the practical reality of our early translational research completed at the University of Wisconsin in the second decade of discovery (1980s). The "Tamoxifen Team" discovered selective estrogen receptor modulation and tamoxifen and raloxifene were both now classified as SERMs (Jordan, 2001). But the realization that tamoxifen could not possibly have widespread use because it increases the risk (though this is very small) of endometrial cancer in postmenopausal women (Gottardis et al., 1988), naturally guided us to our new SERM strategy in the late 1980s. We discovered that SERMs maintain bone density (Jordan et al., 1987) and therefore could potentially prevent osteoporosis with the beneficial antiestrogenic side effect of preventing breast cancer (Gottardis and Jordan, 1987). We had solid translational research, as we had found that tamoxifen built bone both in the laboratory (Jordan et al., 1987) and in clinical trial (Love et al., 1992). Raloxifene has a better safety profile and does not increase the risk of endometrial cancer (Cummings et al., 1999), but it does not reduce the risk of coronary heart disease. I think the new SERM, lasofoxifene (Cummings et al., 2010), is very good, as it prevents osteoporosis, breast cancer, coronary heart disease and strokes, but without an increase of endometrial cancer. The problem is how to advance in a crowded market with low budgets for marketing. Lasofoxifene is approved but not marketed in the European Union.

No molecule targeting estrogen receptor has, to date, proved to be more efficient than tamoxifen in patients despite the development of a number of promising compounds. How do you explain that? Was it a choice of the pharmaceutical industry because of the cost of the development of such a compound?

The issue with tamoxifen is unique. It was clearly lucky that tamoxifen had an acceptable toxicology profile for the treatment of cancer. It came onto the market at a time when the standard of care was combination cytotoxic chemotherapy, so tamoxifen looked good to patients. Tamoxifen was not supposed to succeed, but advanced from strength to strength for twenty years. However, things change very rapidly in the arena of patient preference. In the early 1990s, when tamoxifen was being considered for testing as a chemopreventive and the specter of endometrial cancer translated from the laboratory (Gottardis et al., 1988) to clinical practice, this was clearly not good news for well women. Worse still, tamoxifen was found to produce DNA adducts in rat liver and initiate rat liver hepatocarcinogensis (Jordan, 1995). Although liver tumors did not translate to clinical practice, this did not lessen concern, as the drug ended up with a black box label as a human carcinogen. Timing is everything with discovery and competitors could never catch up with clinical testing, despite the fact they may have been safer. We will never know.

To demonstrate that natural or synthetic molecules can prevent the occurrence of cancer is long and expensive. This raises the question of the life of the patents but also the natural molecules, which may not be patentable. Do you think there may be solutions to these problems?

I think it's currently impossible to find a solution to this dilemma. Clearly, the pharmaceutical industry will never advance with twenty year studies because the patents will run out. But here is a controversial point: the success of health care has now created the situation of increased longevity, so that drugs that enhance survival through prevention can only make matters worse. What is society to do? How does society find the resources to support an aging population?

You have developed recently a very provocative approach using estrogens for the treatment of breast cancers. This can be considered as a paradoxical use of estrogens? Could you explain to us a little bit about that.

The third and fourth decades have been a wonderful surprise in our journey of discovery. We posed the question (based upon the clinical acceptance of long term antihormonal therapy (Jordan, 2008 a) as the most appropriate adjuvant treatment for breast cancer): what is the mechanism and the timeframe for acquired antihormone resistance? Our first model clearly showed something unique as far as drug resistance is concerned-SERM-stimulated growth, something that is not seen with any other drug in cancer therapy (Gottardis and Jordan, 1988). This form of resistance occurred within a year or two and was consistent with the development of acquired resistance to tamoxifen in metastatic breast cancer. However, here was the dilemma: this model did not replicate the outstanding success observed with five years of adjuvant tamoxifen treatment (Early Breast Cancer Trialists' Collaborative Group (EBCTCG), 2011). In fact, five years of treatment continues to enhance decreases in mortality for more than a decade once tamoxifen is stopped. By a series of lucky accidents, one of my students (Doug Wolf) discovered that physiologic estrogen could cause dramatic tumor regression after five years of tamoxifen treatment, i.e. serial transplantation of tamoxifen-resistant tumors into generations of 


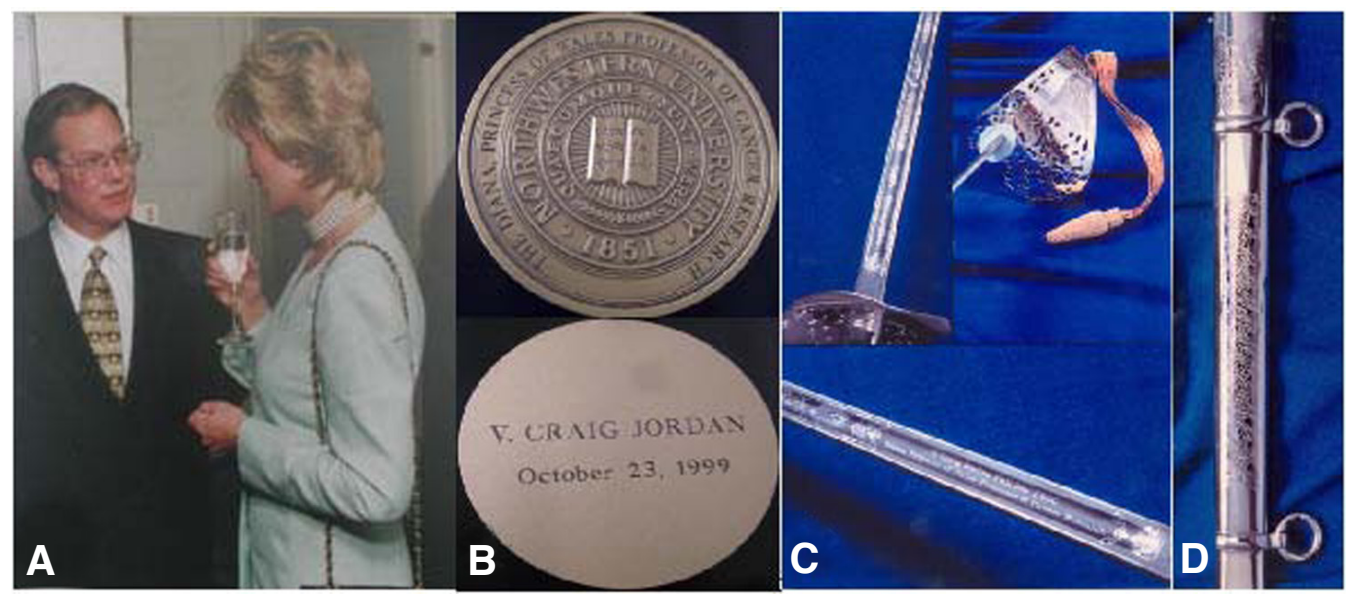

Fig. 5. The Diana, Princess of Wales Chair of Cancer Research. In June 1996, Diana, the Princess of Wales visited Chicago for three days and we first met (A) at the evening reception at the home of the President of Northwestern University, Henry Bienen. The Chair was anonymously endowed at the Robert H. Lurie Comprehensive Cancer Center after Diana's untimely death on August 31, 1997. I was inaugurated on October 23, 1999, being presented with a unique Professorial medal (B) with copies being sent to her sons Prince William and Harry and also kept by my daughters, Helen and Alexandra. My students presented me with an engraved sword (C) to commemorate the event and their names and the dates of the award of their PhD degrees are engraved on the scabbard (D).

tamoxifen-treated mice (Wolf and Jordan, 1993). This discovery reminded me of the words of Sir Alexander Haddow, FRS in 1970 during the Inaugural Karnofsky Lecture at the American Society of Clinical Oncology (ASCO): “...the extraordinary extent of tumour regression observed in perhaps $1 \%$ of post-menopausal cases (with oestrogen) has always been regarded as of major theoretical importance, and it is a matter for some disappointment that so much of the underlying mechanisms continues to elude us..." (Haddow, 1970). It is now clear that aggressive estrogen deprivation with aromatase inhibitors or SERMs can rapidly re-configure breast cancer cells through an evolution of drug resistance, which exposes a vulnerability that could not be anticipated-physiological estrogen induced apoptosis (Yao, 2000; Lewis et al., 2005). When Haddow did his original work using high dose DES for the treatment of metastatic breast cancer in women during their late sixties and seventies, the best therapeutic results occurred the further away the patient was from the menopause. Antihormone therapy accelerates all of that in breast cancer, so physiologic estrogen can initiate the same triggering mechanism. Indeed, this is possibly the same mechanism that is occurring in the Women's Health Initiative (WHI) by conjugated equine estrogen (CEE) alone actually produces a decrease in the incidence of breast cancer in hysterectomized postmenopausal women (La Croix et al., 2011). What is particularly interesting about these data is the six years of monitoring after CEE is stopped, there is a continued reduction in the incidence of breast cancer, i.e. the estrogen has destroyed the nascent breast cancer cells in the ducts (Jordan and Ford, 2011). Our current laboratory work is focused entirely on deciphering the molecular mechanism of estrogen-induced apoptosis (Ariazi, in press). In this way, we may find the vulnerability triggered by the ER estrogen complex for cellular destruction; that vulnerable site in the cancer cell may be the next target for a new class of selective anticancer agents applicable to sites other than breast cancer.

Your contributions to medicine have received a lot of recognition (Table 1) but how does one become the "Diana, Princess of Wales Professor of Cancer Research"?!

Life is all about chance meetings. In the mid-1990s, I was invited to organize a Breast Cancer Symposium in Chicago, and Diana was my Keynote Speaker (Fig. 5). She came on a three day visit to Northwestern University and the Robert H. Lurie Comprehensive
Cancer Center. Naturally, it was a very special time and when she left to return to London, we agreed to correspond and I sent her copies of my books on tamoxifen. There was even talk of a return trip for either her or Prince William or Prince Harry, to open one of our new research buildings. Regrettably, everything changed with her untimely death in a tragic car accident in Paris on August 31,1997 . An anonymous donation was subsequently made to the Robert H. Lurie Comprehensive Cancer Center, and with letters from Lady Sarah McCorquodale, (her sister) and the Earl Spencer (her brother), it was agreed that I would hold a Professorship at

TABLE 1

\section{AWARDS \& HONORS}

\begin{tabular}{|c|c|}
\hline St. Gallen International Breast Cancer Prize & 2011 \\
\hline Elected to the National Academy of Sciences, USA (Fig. 6) & 2009 \\
\hline $\begin{array}{l}\text { Elected Fellow of the Academy of Medical Sciences (UK equivalent } \\
\text { of Inst.of Medicine in the US) }\end{array}$ & 2009 \\
\hline Elected Fellow of the Society of Biology (UK) & 2009 \\
\hline Honorary Doctor of Medicine Degree, University of Crete, Greece & 2009 \\
\hline $39^{\text {th }}$ David A. Karnofsky Award, ASCO & 2008 \\
\hline Honorary Fellowship of the Royal Society of Medicine (Fig. 7) & 2008 \\
\hline $\begin{array}{l}\text { Honorary Member of the Royal Pharmaceutical Society of Great } \\
\text { Britain }\end{array}$ & 2008 \\
\hline $\begin{array}{l}\text { Gregory Pincus Award and Medal, Worcester Foundation for } \\
\text { Biomedical Research, U. Mass }\end{array}$ & 2007 \\
\hline American Cancer Society Award for Chemoprevention, ASCO & 2006 \\
\hline Honorary Doctor of Science Degree, University of Bradford, England & 2005 \\
\hline $\begin{array}{l}\text { Alfred G. Knudson Jr. Chair in Basic Science, Fox Chase Cancer } \\
\text { Center }\end{array}$ & 2004 \\
\hline $\begin{array}{l}3^{\text {rd }} \text { George and Christine Sosnovsky Award in Cancer Therapy, } \\
\text { Royal Society of Chemistry }\end{array}$ & 2003 \\
\hline The Kettering Prize, General Motors Cancer Research Foundation & 2003 \\
\hline $\begin{array}{l}\text { Officer of the Most Excellent Order of the British Empire (OBE) } \\
\text { Services to International Breast Cancer Research }\end{array}$ & 2002 \\
\hline American Cancer Society Medal of Honor & 2002 \\
\hline Inaugural Dorothy P. Landon AACR Prize in Translational Research & 2002 \\
\hline $\begin{array}{l}\text { Bristol Myers Squibb Award for Distinguished Achievement in Cancer } \\
\text { Research }\end{array}$ & 2001 \\
\hline Honorary Doctor of Medicine Degree, University of Leeds & 2001 \\
\hline European Institute of Oncology Breast Cancer Therapy Award & 2001 \\
\hline Honorary Doctor of Science Degree, University of Massachusetts & 2001 \\
\hline Honorary Faculty Fellowship Award, University College, Dublin & 2000 \\
\hline $\begin{array}{l}\text { Diana, Princess of Wales Professor of Cancer Research, Robert H. } \\
\text { Lurie Comprehensive Cancer Center }\end{array}$ & 1999 \\
\hline
\end{tabular}


Northwestern University in her name. Essentially, it was my British citizenship, a British medicine (tamoxifen), and our meeting and correspondence that was important to the family. On October 23, 1999, the Professorship was conferred on me by Henry Bienen, the President of Northwestern University and over a two day period, there was a Symposium in my honor by my former PhD students and during the celebration dinner, attended by representatives from the British Embassy, Barry Furr (the Chief Scientist from $\mathrm{ICI}$ ), family, friends and colleagues, my students presented me with an engraved sword (Fig. 5) with each of the dates of their Ph.D engraved on the scabbard as battle honors - very moving!

You have contributed more than 600 research and review papers to the literature with more than 23,000 citations and an $\mathbf{h}$-index of $\mathbf{8 0}$. If you had to select ten of your research papers and three reviews, which would they be and why?

Jordan V.C. (1976). Eur J Cancer 12: 419-424. Literally my first cancer research paper with tamoxifen that was rejected in 1974, but with kind and generous comments from one of the reviewers. I persevered and eventually this was one of the papers from my work used to justify the chemoprevention trials.

Jordan V.C. and Allen K.E. (1980). Eur J Cancer 16: 239-251. The paper makes three points: 1 . this is the first refereed article that longer treatment is going to be better than shorter treatment; 2. our discovery of 4-hydroxytamoxifen's pharmacology indicating it to be a potent antiestrogen with a binding affinity for ER equivalent to estradiols (Jordan et al., 1977), naturally made us think that this would be a more powerful anticancer agent-not true, it cleared too quickly and 3. finally, we stated that antiestrogen treatment followed by estrogen deprivation would be a good strategy for people-true.

Gottardis M.M., et al.,1988). Cancer Res 48: 812-815. This was the paper that warned the clinical community that tamoxifen could potentially increase the incidence of endometrial cancer in patients-true.

Gottardis M.M. and Jordan V.C. (1988). CancerRes48:5183-5187. This was the first report that acquired drug resistance with tamoxifen was unique and stimulated by SERMs-true.

Love R.R., et al.,1992). New EnglJ Med 326: 852-856. This was the randomized clinical trial based on our laboratory evidence and subsequently those of others that tamoxifen would maintain bone density in people. This paper opened the door to raloxifene.

Levenson A.S. and Jordan V.C (1998). CancerRes58: 1872-1875. Aclean demonstration that a mutant ER found in a tamoxifen-stimulated tumor by a previous PhD student (Doug Wolf) could change an antiestrogen to an estrogen. This could be done by a natural process.

Cummings S.R., et al.,1999). JAMA 281: 2189-2197. Proof of principle that the concept we first articulated back in the late 1980s that you could develop a SERM to prevent osteoporosis and prevent breast cancer at the same time-true.

Yao K., et al.,2000). Clin Cancer Res 6: 2028-2036. The first refereed publication to demonstrate that drug resistance to tamoxifen evolves and exposes a vulnerability to permit physiologic estrogen to cause tumor regression. Subsequently translated to the clinic-true.

Vogel V.G., et al.,2006). The Study of Tamoxifen and Raloxifene (STAR): Report of the National Surgical Adjuvant Breast and Bowel Project P-2 Trial. JAMA. 295: 2727-2741. Two discarded drugs from the pharmaceutical industry that were re-invented in the same pharmacology laboratory to become the pioneering chemopreventive agents and FDA-approved-true.

Vogel V.G., etal.,2010). CancerPrevRes 3:696-706. A follow-up of the trial several years after stopping SERM treatment, confirmed the predictions of one of my PhD students (Marco Gottardis) in 1987 that tamoxifen would be the better chemopreventive in the long term.

l've always viewed an invitation to write a review article from a journal as a wonderful opportunity to project your personality, express your views and most importantly, reach out to young scientists and graduate students as theirs is the future. Here are my three choices:

Jordan V.C. (1984). Pharm Rev 36: 245-276. This was my first major review when I first came to America. No one had really treated the topic as an issue in pharmacology, as all of the previous reviews in the 1960s and 1970s were about the control of fertility. I wanted a summary of the mechanisms of action of antiestrogens. It was all of our knowledge up to that point (423 citations).

Jordan V.C. (2006). Br J Pharmacol 147: S269-S276. I was thrilled to be asked by the British Pharmacological Society to write the story of my research in a Special Issue of our Journal. I got

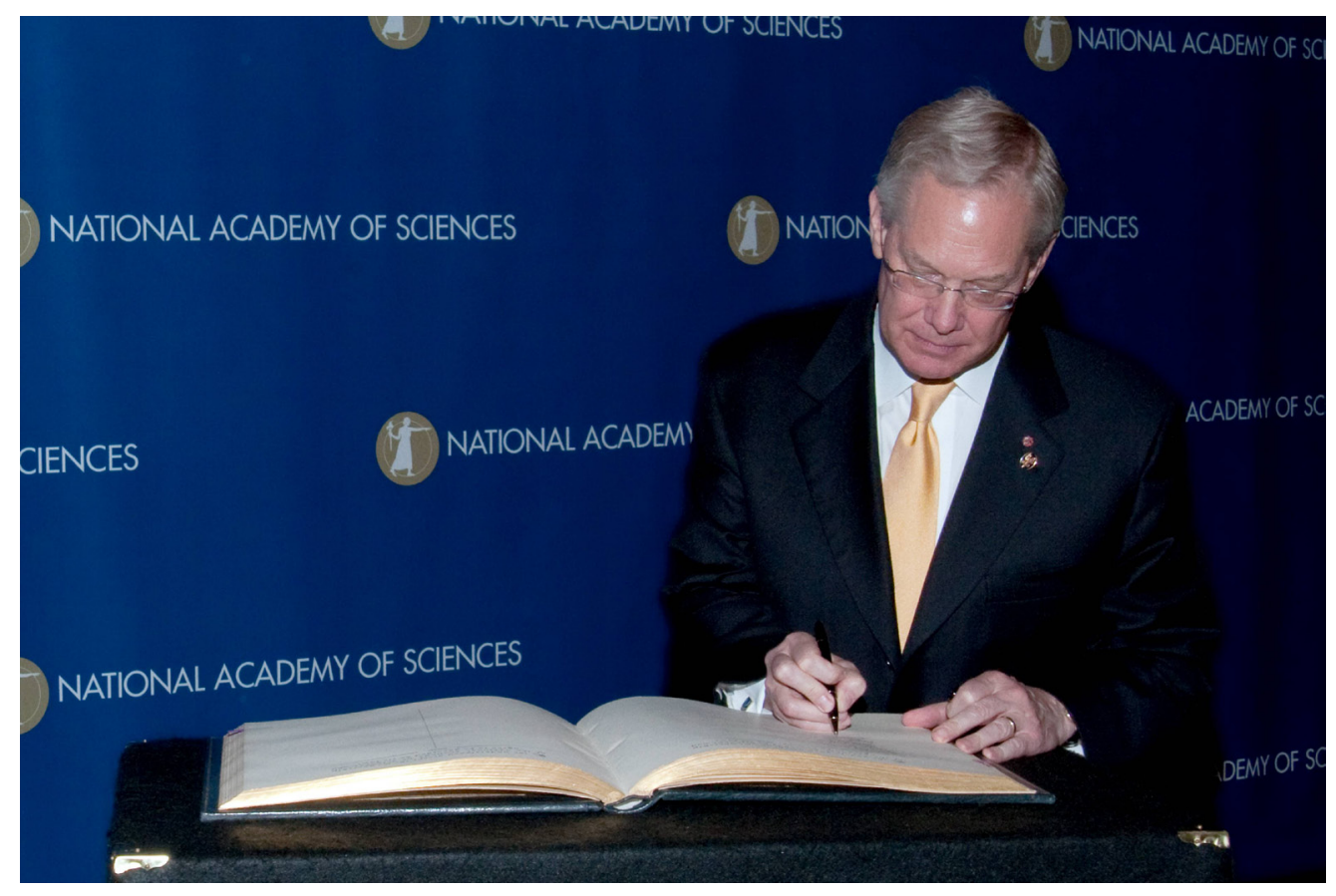

Fig. 6. Signing the "Great Book" of Members of the National Academy of the Sciences USA during the Induction Ceremony on April 24, 2010. 
wonderful feedback from students.

JordanV.C. (2009). Cancer Res. 69: 1243-1254. I was proud to be asked by the American Association for Cancer Research (AACR) to contribute a review of progress in hormone dependent tumors as a part of a series to celebrate the $100^{\text {th }}$ anniversary of AACR.

I see that you received the David A. Karnofsky Award in 2008 from ASCO, but it is stated in the regulations for the Award that it is given in "recognition of innovative clinical research and developments that have changed the way oncologists think about the general practice of oncology." You are a laboratory scientist and not a clinician; didn't this surprise you?

When I received the telephone call from the Chair of the Awards Committee, Gabriel Hortobagyi, I was absolutely dumbfounded, because naturally, I knew I was not a clinician! All previous recipients were clinicians. This is ASCO's highest award, and I was being asked to join the legends of clinical practice. For the first fifteen minutes of my conversation with Gabriel, I examined with him every reason why I should not be their recipient. After fifteen minutes, he became exasperated and said, "Is this a yes, I accept?" I accepted the honor. Apparently, I learned, the reason the Committee selected my work was because as a laboratory scientist and a pharmacologist, I had always been present at clinical breast

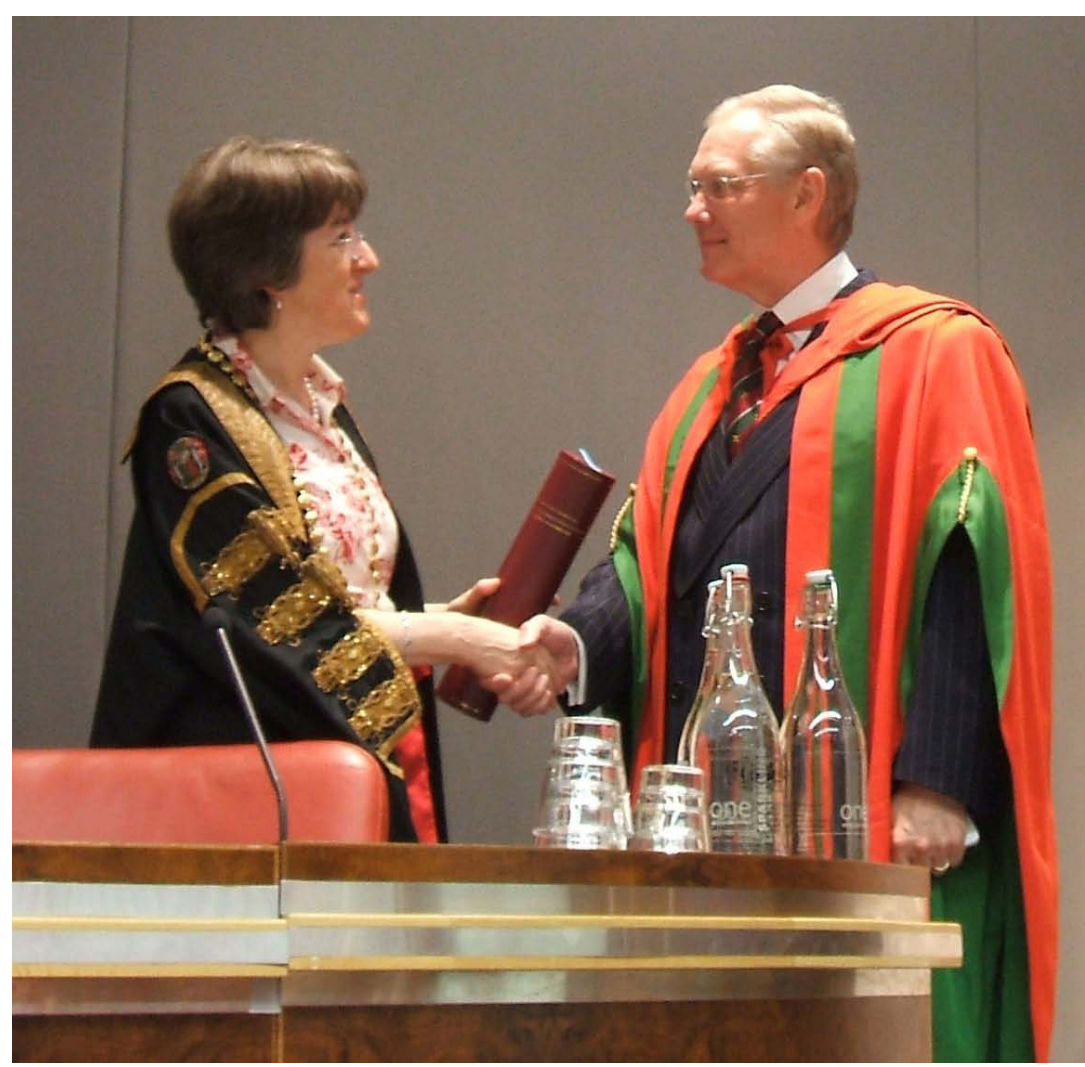

Fig. 7. Honorary Fellowship of the Royal Society of Medicine awarded by Professor Ilora Finlay, Baroness Finlay of Llandaff, President of the Royal Society of Medicine (2008). This honor is awarded to individuals of international standing who have eminently distinguished themselves in the service of medicine and the fields which influence it. The Society permits, at most, 100 people into this elite group at any one time. In 2008 there were only 89 Honorary Fellows worldwide. In 2009, I received the Jephcott Medal from the Royal Society of Medicine, and in 2010, I was elected as the President of the Royal Society of Medicine Foundation in North America. cancer meetings over the decades, putting forward my point-of-view in cancer treatment with SERMs. For me, the promise of life was the most important goal. But safety was essential. The involvement I had every day with the clinical evaluation of tamoxifen (Love et al., 1992), followed by leadership positions for the evaluation of raloxifene (Cummings et al., 1999), and then as the Scientific Chair of the Study of Tamoxifen and Raloxifene (STAR) (Vogel et al., 2006, 2010) allowed me to deploy the knowledge generated by my "Tamoxifen Team" over decades to save lives and advance women's health (Jordan, 2008 b). Please remember that when I started this improbable and unlikely journey at the beginning of the 1970s, cancer therapeutics with a targeted agent, chemoprevention, and the drug group, SERMs (or even tamoxifen for that matter!) did not exist. Cancer research was not recommended as career for the pharmacologist and the pharmacologist would no knowingly venture into women's health. All of the revenues in the pharmaceutical industry were derived from heart drugs and drugs that affected the central nervous system (e.g. tranquilizers, etc.).

When I was starting the research for my PhD at Leeds University, Sir Alexander Haddow, FRS in the Inaugural Karnofsky Lecture (Haddow, 1970), was dismayed at the prospect for cancer therapeutics. Unlike the success noted with antibiotics for the treatment of different infectious diseases, there were no laboratory tests to establish whether a chemotherapy would be effective or not. The physician just had to give it to the patient and see if it worked! Haddow was also not convinced that a cancer-specific drug could be developed because cancer was self. In Haddow's Karnofsky Lecture publication, there was one glimmer of hope: Haddow had used the first chemical therapy to treat any cancer, i.e. high dose estrogen to treat metastatic breast cancer in women in their late sixties and seventies. He observed that some of the responses just melted the tumors away. But he was dismayed that the mechanisms had remained elusive. I am pleased to say that we have now solved the question surrounding the mechanism of estrogen-induced apoptosis (Ariazi, in press).

It is fair to say that the work that has evolved and developed on the treatment and prevention of breast cancer over the past four decades has changed our outlook and replaced pessimism with hope. The first decade of discovery was essential to move forward in the field (Jordan, $2008 \mathrm{a}$ ). It has not only been possible to create change in medical practice, but the laboratory principles all translated to patient care to save or at least extend lives. That is what pharmacology is.

In closing, I must end where we began. I have thanked Drs. Kaye and Clark (Fig. 1) many times for the opportunity they gave me with a place at Leeds University. The reply I received was usually "we were only doing our job." Good words to remember and live by.

\section{Acknowledgements}

Dr. Jordan wishes to thank all of his "Tamoxifen Teams", who for the past four decades have converted ideas into lives saved. Dr. Jordan wishes to thank the Department of Defense Breast Program under Award number W81XWH-06-1-0590 Center of Excellence; subcontract under the SU2C (AACR) Grant number SU2C-AACR-DT0409; the Susan G Komen For The Cure Foundation under Award number SAC100009 
and the Lombardi Comprehensive Cancer Center Support Grant (CCSG) Core Grant NIH P30 CA051008 for his current research funding. The views and opinions of the author(s) do not reflect those of the US Army or the Department of Defense.

\section{References}

ARIAZI E.A., CUNLIFFE H.E., LEWIS-WAMBI J.S., SLIFKER M.J., WILLIS A.L., RAMOS P., TAPIA C., KIM H.R., YERRUM S., SHARMA C.G.N., NICOLAS E., BALAGURUNATHAN Y., ROSS E.A. and JORDAN V.C. (in press). Estrogen Induces Apoptosis in Estrogen Deprivation-resistant Breast Cancer via Stress Responses as Identified by Global Gene Expression. Proc Natl Acad Sci USA.

CUMMINGS S.R., ECKERT S., KRUEGER K.A., GRADY D., POWLES T.J., CAULEY J.A., NORTON L., NICKELSEN T., BJARNASON N.H., MORROW M., LIPPMAN M.E., BLACK D., GLUSMAN J.E., COSTAA. and JORDAN V.C. (1999). The effect of raloxifene on risk of breast cancer in postmenopausal women: results from the MORE randomized trial. JAMA 281: 2189-2197.

CUMMINGSS.R., ENSRUD K., DELMAS P.D., REIDD.M., GOLDSTEIN S., SRIRAM U., LEE A., THOMPSON J., ARMSTRONG R.A., THOMPSON D.D., POWLEST., ZANCHETTA J., KENDLER D., NEVEN P. and EASTELL R. (2010). Lasofoxifene in postmenopausal women with osteoporosis. New Engl J Med 362: 686-696.

EARLY BREAST CANCER TRIALISTS' COLLABORATIVE GROUP (EBCTCG). (2011). Relevance of breast cancer hormone receptors and other factors to the efficacy of adjuvant tamoxifen: patient-level meta-analysis of randomised trials. Lancet 378: 771-784.

GOTTARDIS M.M. and JORDAN V.C. (1987). The antitumor actions of keoxifene (raloxifene) and tamoxifen in the $\mathrm{N}$-nitrosomethylurea-induced rat mammary carcinoma model. Cancer Res 47: 4020-4024.

GOTTARDIS M.M. and JORDAN V.C. (1988). Development of tamoxifen-stimulated growth of MCF-7 tumors in athymic mice after long-term antiestrogen administration. Cancer Res 48: 5183-5187.

GOTTARDIS M.M., ROBINSON S.P., SATYASWAROOP P.G. and JORDAN V.C. (1988). Contrasting actions of tamoxifen on endometrial and breast tumor growth in the athymic mouse. Cancer Res. 48: 812-815.

HADDOW A. (1970). David A. Karnofsky memorial lecture. Thoughts on chemical therapy. Cancer 26: 737-754.

JORDAN V.C. and KOERNER S. (1975). Tamoxifen (ICI 46,474) and the human carcinoma 8S oestrogen receptor. Eur J Cancer 11: 205-206.

JORDAN V.C. (1976). Effect of tamoxifen (ICI 46,474) on initiation and growth of DMBA-induced rat mammary carcinomata. Eur J Cancer. 12: 419-424.

JORDAN V.C, COLLINS M.M., ROWSBY L. and PRESTWICH G. (1977). A monohydroxylated metabolite of tamoxifen with potent antioestrogenic activity. $J$ Endocrinol 75: 305-316.

JORDAN V.C. (1978). Use of the DMBA-induced rat mammary carcinoma system for the evaluation of tamoxifen as a potential adjuvant therapy. Rev on Endocr Relat Cancer 49-55.

JORDAN V.C., DIX C.J. and ALLEN K.E. (1979). The effectiveness of long term tamoxifen treatment in a laboratory model for adjuvant hormone therapy of breast cancer. In Adjuvant Therapy of Cancer II (Eds. S.E. Salmon and S. E. Jones). Grune \& Stratton Inc., Philadelphia, pp. 19-26.

JORDAN V.C. and ALLEN K.E. (1980). Evaluation of the antitumour activity of the nonsteroidal antioestrogen monohydroxytamoxifen in the DMBA-induced rat mammary carcinoma model. Eur J Cancer 16: 239-251.

JORDAN V.C. and LIEBERMAN M.E. (1984). Estrogen-stimulated prolactin synthesis in vitro classification of agonists, partial agonist and antagonist actions based on structure. Mol Pharm 26: 279-285.

JORDAN V.C. (1984). Biochemical pharmacology of antiestrogen action. Pharm Rev 36: 245-276.

JORDAN V.C., PHELPS E. and LINDGREN J.U. (1987). Effects of antiestrogens on bone in castrated and intact female rats. Breast Cancer Res Treat 10: 31-35.

JORDAN V.C. (1988). The development of tamoxifen for breast cancer therapy: a tribute to the late Arthur L. Walpole. Breast Cancer Res Treat 11: 197-209.

JORDAN V.C. (1995). What if tamoxifen (ICI 46,474) had been found to produce liver tumors in rats in 1973? Ann Oncol 6: 29-43.
JORDAN V.C. (2001). Selective Estrogen Receptor Modulation: a personal perspective. (Perspectives in Cancer Research). Cancer Res 61: 5683-5687.

JORDAN V.C. (2003). Tamoxifen: a most unlikely pioneering medicine. Nat Rev Drug Discov 2: 205-213.

JORDAN V.C. (2006). $75^{\text {th }}$ Anniversary Edition British Journal of Pharmacology Special Issue. Tamoxifen (ICI 46,474) as a targeted therapy to treat and prevent breast cancer. Br J Pharmacol 147: S269-S276.

JORDAN V.C. (2007). Chemoprevention of Breast Cancer with Selective Oestrogen Receptor Modulators. Nat Rev Cancer 7: 46-53.

JORDAN V.C. (2008 a). Tamoxifen: catalyst for the change to targeted therapy. Eur J Cancer 44: 30-38.

JORDAN V.C. (2008 b). The 38th David A. Karnofsky lecture: the paradoxical actions of estrogen in breast cancer--survival or death? J Clin Oncol 26: 3073-3082.

JORDAN V.C. (2009). A century of deciphering the control mechanisms of sex steroid action in breast and prostate cancer: the origins of targeted therapy and chemoprevention. Cancer Res 69: 1243-1254.

JORDAN V.C. and FORD L.S. (2011). Paradoxical Clinical Effect of Estrogen on Breast Cancer Risk: A "New" Biology of Estrogen-Induced Apoptosis. Cancer Prev Res 4: 633-637.

LACROIXA.Z., CHLEBOWSKI R.T., MANSON J.E., ARAGAKIA.K., JOHNSON K.C. MARTIN L., MARGOLIS K.L., STEFANICK M.L., BRZYSKI R., CURB J.D., HOWARD B.V., LEWIS C.E. and WACTAWSKI-WENDE, J. (2011). Health outcomes after stopping conjugated equines estrogens among postmenopausal women with prior hysterectomy: a randomized controlled trial. JAMA 205: 1305-1314.

LEVENSON A.S. and JORDAN V.C. (1998). The key to the antiestrogenic mechanism of raloxifene is Amino Acid 351 (Asp) in the estrogen receptor. Cancer Res 58: 1872-1875.

LEWIS J.S., MEEKE K., OSIPO C., ROSS E.A., KIDAWI N., LI Y., BELL E., CHANDEL N.S. and JORDAN V.C. (2005). Intrinsic mechanism of estradiol-induced apoptosis in breast cancer cells resistant to estrogen deprivation. J Natl Cancer Inst 97: 1746-1759.

LIEBERMAN M.E., JORDAN V.C., FRITSCHM., SANTOS M.A. and GORSKI J. (1983 a). Direct and reversible inhibition of estradiol-stimulated prolactin synthesis by antiestrogens in vitro. J Biol Chem 258: 4734-4740.

LIEBERMAN M.E., GORSKI J. and JORDAN V.C. (1983 b). An estrogen receptor model to describe the regulation of prolactin synthesis by antiestrogens in vitro. J Biol Chem 258: 4741-4745.

LIU H., LEE E.S., DE LOS REYESA., ZAPF J.W. and JORDAN V.C. (2001). Silencing and reactivation of the selective estrogen receptor modulator (SERM)-ER alpha complex. Cancer Res 61: 3632-3639.

LIU H., PARK W., BENTREM D.J., MCKIAN K.P., DELOS REYES A., MACGREGORSCHAFER J., ZAPF J. and JORDAN V.C. (2002). Structure-function relationships of the raloxifene-estrogen receptor alpha complex for regulating transforming growth factor alpha expression in breast cancer cells. J Biol Chem 277:9189-9198.

LOVE R.R., MAZESS R.B., BARDEN H.S., EPSTEIN S., NEWCOMB P.A., JORDAN V.C., CARBONE P.P. and DEMETS D.L. (1992). Effects of tamoxifen on bone mineral density in postmenopausal women with breast cancer. New Engl J Med 326: 852-856

MACGREGOR-SCHAFER J.I., LIU H., BENTREM D., ZAPF J. And JORDAN V.C. (2000). Allosteric silencing of activating function 1 in the 4-hydroxytamoxifen estrogen receptor complex by substituting glycine for aspartate at amino acid 351. Cancer Res 60: 5097-5105.

VOGEL V.G., COSTANTINO J.P., WICKERHAM D.L., CRONIN W.M., CECCHINI R.S., ATKINS J.N., BEVERS T.B., FEHRENBACHER L., PAJON E.R., WADE J.L., ROBIDOUXA., MARGOLESER.G., JAMES J., LIPPMAN S.M., RUNOWICZ C.D., GANZ P.A., REIS S.E., MCCASKILL-STEVENS W., FORD L.G., JORDAN V.C. and WOLMARK N. (2006). The Study of Tamoxifen and Raloxifene (STAR): Report of the National Surgical Adjuvant Breast and Bowel Project P-2 Trial. JAMA 295: 2727-2741.

VOGEL V.G., COSTANTINO J.P., WICKERHAM D.L., CRONIN W.M., CECCHINI R.S., ATKINS J.N., BEVERS T.B., FEHRENBACHER L., PAJON E.R., WADE J.L., ROBIDOUX A., MARGOLESE R.G., JAMES J., RUNOWICZ C.D., GANZ P.A., REIS S.E., MCCASKILL-STEVENSW., FORD L.G., JORDAN V.C. and WOLMARK N. (2010). Update of the NSABP Study of Tamoxifen and Raloxifene (STAR) P-2 
Trial: Preventing Breast Cancer. Cancer Prev Res 3: 696-706.

WOLF D.M. and JORDAN V.C. (1993). A laboratory model to explain the survival advantage observed in patients taking adjuvent tamoxifen therapy. Recent Results Cancer Res 127: 23-33

WOLF D.M. and JORDAN V.C. (1994). The estrogen receptor from a tamoxifen stimulated MCF-7 tumor variant contains a point mutation in the ligand binding domain. Breast Cancer Res Treat 31: 129-138.

YAO K., LEE E.S., BENTREM D.J., ENGLAND G., SCHAFER J.I.M., O’REGAN R. and JORDAN V.C. (2000). Antitumor action of physiologic estradiol on tamoxifenstimulated breast tumors grown in athymic mice. Clin Cancer Res 6: 2028-2036.

\section{Further Related Reading, published previously in the Int. J. Dev. Biol.}

Estrogenic in vitro assay on mouse embryonic Leydig cells.

Gina La Sala, Donatella Farini and Massimo De Felici.

Int. J. Dev. Biol. (2010) 54: 717-722

Estrogen regulation of placental angiogenesis and fetal ovarian development during primate pregnancy.

Eugene D. Albrecht and Gerald J. Pepe.

Int. J. Dev. Biol. (2010) 54: 397-407

Casein kinase I epsilon somatic mutations found in breast cancer cause overgrowth in Drosophila.

Tomas Dolezal, Katerina Kucerova, Jana Neuhold and Peter J. Bryant.

Int. J. Dev. Biol. (2010) 54: 1419-1424

Epithelial-Mesenchymal Transitions in development and disease: old views and new perspectives

M. Angela Nieto.

Int. J. Dev. Biol. (2009) 53: 1541-1547

The expression of the imprinted gene Ipl is restricted to extra-embryonic tissues and embryonic lateral mesoderm during early mouse development.

Sally L Dunwoodie and Rosa S P Beddington

Int. J. Dev. Biol. (2002) 46: 459-466

Germ cells, gonads and sex reversal in marsupials.

M B Renfree and G Shaw.

Int. J. Dev. Biol. (2001) 45: 557-567

Detection of sex-specific proteins in chick embryo gonads and mesonephros: effects of estradiol benzoate or tamoxifen on their expression.

R Didier and Y Croisille.

Int. J. Dev. Biol. (1989) 33: 467-475

5 yr ISI Impact Factor $(2010)=2.961$

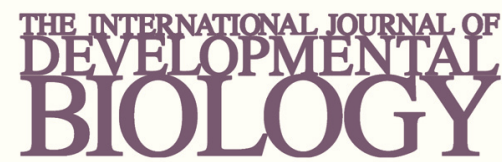

Volume 54 Nos. 6/7

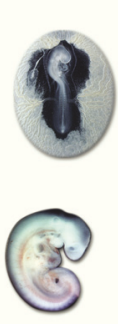

Special Issue

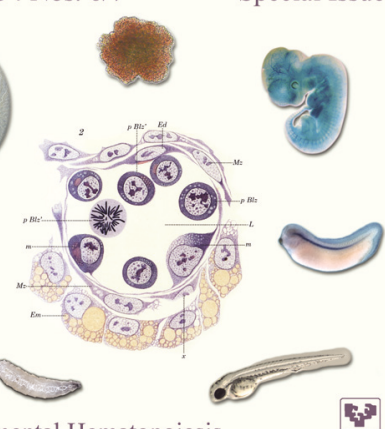

Developmental Hematopoiesis
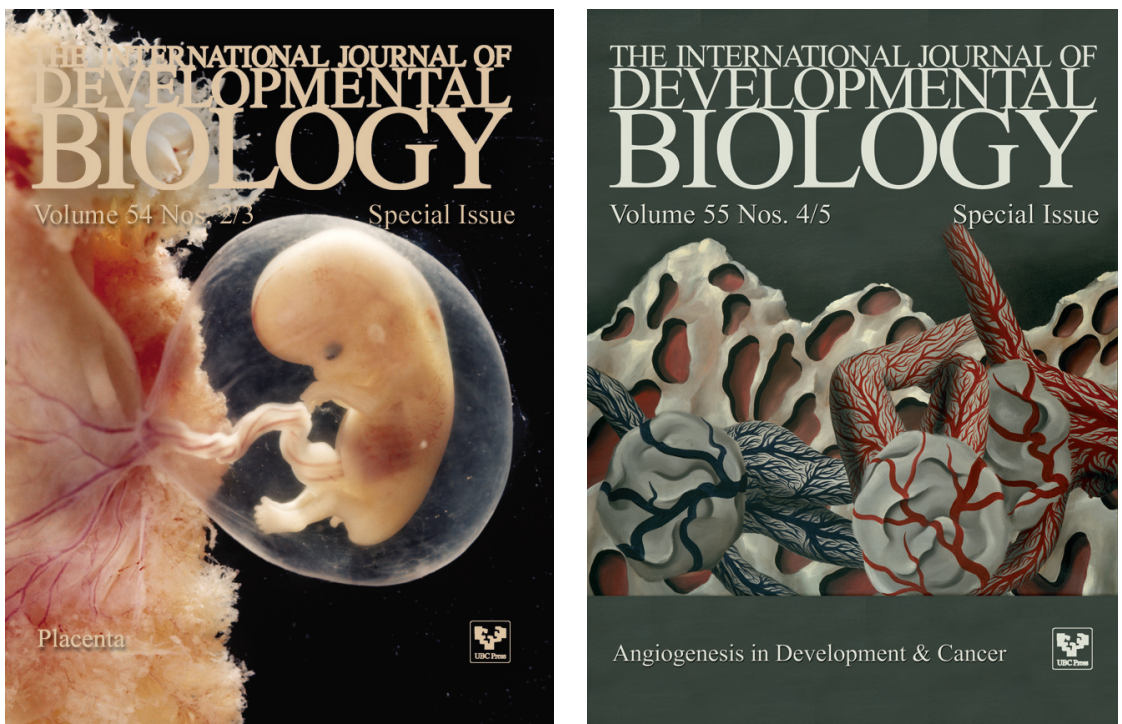